\title{
HUBUNGAN PERSEPSI MASYARAKAT TERHADAP PEMERINTAH DENGAN KECEMASAN MENGHADAPI RENCANA PEMBANGUNAN JALUR GANDA KERETA API
}

\author{
Budi Cakra Buana dan Udi Rosida Hijrianti \\ Fakultas Psikologi, Universitas Muhammadiyah Malang, Jl. Raya Tlogomas No.246 Malang 65144 \\ Email : Budicak07@gmail.com,*udi@umm.ac.id
}

\begin{abstract}
Abstrak
Persepsi masyarakat terhadap pemerintah menimbulkan suatu pandangan dari masing-masing masyarakat akan kebijakan yang diberikan oleh pemerintah baik itu persepsi positif maupun negatif. Persepsi negatif tersebut memicu adanya suatu kecemasan masyarakat apabila rumah yang ditinggali terancam terkena penggusuran. Oleh karena itu, tujuan dalam penelitian ini untuk mengetahui hubungan antara persepsi masyarakat terhadap pemerintah dengan kecemasan menghadapi rencana pembangunan jalur ganda kereta api pada warga Pulosari Kecamatan Blimbing Kota Malang. Metode yang digunakan merupakan metode kuantitatif korelasional, dengan teknik purposive sampling. Subjek penelitian berjumlah 77 warga Pulosari yang bertempat tinggal di pinggir rel kereta api. Skala yang digunakan pada penelitian ini adalah skala persepsi dan skala kecemasan. Hasil analisis data menggunakan product moment pearson diperoleh $r=-0,74$ dengan $p=$ $0,01<0,05$, sehingga dapat disimpulkan bahwa terdapat hubungan negatif antara persepsi masyarakat terhadap pemerintah dengan kecemasan menghadapi rencana pembangunan jalur ganda kereta api, yang artinya bahwa semakin positif persepsi terhadap pemerintah, maka semakin tidak menimbulkan kecemasan, dan begitupun sebaliknya.
\end{abstract}

Kata Kunci: Persepsi, kecemasan dan warga Pulosari

\section{RELATIONSHIP BETWEEN SOCIETY PERCEPTION OF GOVERNMENT AND ANXIETY AGAINST DOUBLE RAIL TRAIN DEVELOPMENT PLAN}

\begin{abstract}
The perception of the public toward the government is a view of each community will be given by the government policy either positive or negative perceptions. The negative perception trigger feelings of tension, heart palpitations, sweaty body, and anxiety. Thus, the purpose of this study is to investigate the correlation between the public perception of government with anxiety encounter the development plan of double track railway toward Pulosari citizens, Blimbing Malang city. The method that used in this study was quantitative correlation method, by using purposive sampling technique. The subjects in this study were 77 Pulosari citizens who reside in the railroad. The scale that used in this study was perception and anxiety scale. The results of the data analysis that used pearson product moment was $(r=-0,74$ with $p=0,01<0,05)$. It is mean that there was a negative correlation between the public perception of government with anxiety encounter the development plan of double track railway. Thus, more positive their perception toward the government, then it did not cause anxiety.
\end{abstract}

Keywords: perception, anxiety and Pulosari residents

\section{Pendahuluan}

Seiring dengan perkembangan zaman, kebutuhan akan alat transportasi sangat dibutuhkan dalam menunjang setiap kegiatan yang ada pada masyarakat, terlebih lagi masyarakat pengguna alat transportasi berupa kereta api. Perkeretaapian merupakan hal hal yang berkaitan dengan kereta, yang terdiri atas prasarana, sarana, dan sumber daya manusia, serta norma, kriteria, persyaratan, 
Hubungan Persepsi Masyarakat Terhadap Pemerintah Dengan Kecemasan Menghadapi Rencana

Pembangunan Jalur Ganda Kereta Api

Proyeksi, Vol. 14 (2)2019, 94-114

dan prosedur diharapkan dapat terbentuknya alat transportasi kereta api (UU No.23, 2007). Pada masa ini pemerintah berencana membangun alat prasarana jalur ganda kereta api yang diharapkan dapat menunjang kebutuhan transportasi darat di Kota Malang. Saat ini Kota Malang masih memiliki satu jalur kereta api yang menghubungkan dari kota ke kota. Pembangunan jalur ganda kereta api itu merupakan bagian dari pelayanan, sebab bisa memperlancar lalu lintas kereta api. Selain itu, dengan jalur ganda bisa mengurangi risiko keterlambatan penumpang. Gubernur Jawa Timur periode 20132018 Soekarwo mengatakan bahwa pembangunan jalur ganda itu dirasa sangat penting dan bermanfaat bagi kesejahteraan masyarakat serta kemajuan ekonomi Indonesia khususnya wilayah Jawa Timur. Beberapa titik yang hendak dibangun jalur ganda tersebut sering terjadi kemacetan arus lalu lintas saat kereta api lewat. Pembangunan jalur ganda sebenarnya telah dilakukan sejak 2014 yang dimulai dari Solo menuju Ngawi, sedangkan jalur ganda lintas utara Surabaya-Jakarta saat ini sudah mulai beroperasi (Hermawan, 2016).

Kepala Dinas Perhubungan dan Angkutan Jalan (Dishub dan LLAJ) Jawa Timur Wahid Wahyudi, menyatakan pembangunan jalur ganda kereta api jalur Surabaya menuju Solo. Pemprov Jawa Timur mengusulkan kepada pemerintah pusat agar jalur yang sama juga dibangun untuk lintas selatan dari Kota Surabaya menuju Kota Malang. Menurut Wahid, rencana pembangunan jalur ganda dari Kota Surabaya menuju Kota Malang tersebut sudah disampaikan secara resmi oleh Gubernur Jawa Timur Soekarwo kepada Kementrian Perhubungan (Iskandar, 2015). Kementerian perhubungan menawarkan sebuah proyek dalam meningkatkan kapasitas jalur rel kereta api Kota Surabaya menuju Kota Malang kepada perusahaan Rusia yaitu Russian Railways, pihak Russian Railways telah menindaklanjuti dengan melakukan studi mengenai rencana pembangunan jalur ganda kereta api jalur Kota Surabaya menuju Kota Malang. Kepala Biro Komunikasi dan Informasi Publik Kementerian Perhubungan mengungkapkan bahwa akan dibangunnya jalur ganda kereta api jalur Kota Surabaya menuju Kota Malang, yang diharapkan dapat mengurangi kepadatan di jalan raya. Kota Surabaya dan Kota Malang termasuk kota yang memiliki lalu lintas yang padat, sebagian Kota Malang merupakan daerah wisata yang memiliki banyak peminat, hal ini alat transportasi umum seperti kereta api diharapkan mampu mengurangi kemacetan yang ada di Kota Malang (Praditya, 2016).

Kebijakan pemerintah mengenai pembangunan jalur ganda ini menimbulkan banyak perasaan ketidaknyamanan atau keresahan hingga kecemasan pada masyarakat, khususnya yang bertinggal di pinggir rel. Scovel (dalam Mohtasham \& Farnia, 2017) mendefinisikan rasa cemas sebagai suatu keadaan tidak nyaman yang dapat mempengaruhi emosi, dimana individu merasa terancam, dan juga merasa khawatir dalam menghadapi keadaan genting. Keadaan ini disebabkan karena tempat tinggal warga yang bermukim di pinggir rel juga akan terancam mulai dari jalan depan rumah akan dipasang rel bahkan sampai tergusurnya beberapa rumah yang tidak memiliki sertifikat rumah asli.

Kecemasan merupakan suatu emosi yang timbul karena rasa ketakutan oleh setiap individu dalam menangani suatu permasalahan dan mungkin juga dapat merubah perilaku dari individu. Menurut Maina, Mauri, dan Rossi (2016) gangguan cemas yang dialami setiap individu disebabkan oleh meningkatnya tingkat perasaan khawatir dan meningkatnya perasaan tegang pada situasi yang ditakuti, dan menghindari rangsangan atau keadaan yang dapat memicu timbulnya perasaan cemas. Kondisi emosi seperti ini yang dapat mempengaruhi mental dan juga tingkat konsentrasi dari setiap individu. Kecemasan adalah suatu tanda rasa tidak aman atau bahaya yang berasal dari ego bahwa impuls berbahaya akan muncul, hal ini merupakan reaksi tidak sadar akan timbulnya kecenderungan 
depresi yang ditandai oleh kekhawatiran berlebih yang dapat menimbulkan kepanikan atau ketakutan yang berbahaya. Gejala fisik pada individu yang merasakan kecemasan ditandai dengan tubuh berkeringat, gemetar pada bibir dan tangan, napas terengah-engah, jantung berdebar-debar, bibir mulut menjadi kering, sering buang air kecil. Gejala psikologisnya adalah perasaan tegang, iritabilitas, halusinasi, sulit tidur, tidak dapat berkonsentrasi, dan ragu-ragu dalam membuat atau mengambil keputusan (Wani, Sankar, Rakshantha, Nivatha, Sowparnika \& Marak, 2016).

Di lain sisi warga Pulosari berpendapat bahwa Sukarwo selaku gubernur Jawa Timur periode 2013-2018 sudah lama memberikan informasi mengenai pembangunan jalur ganda kereta api pada warga Pulosari Kecamatan Blimbing lewat media koran dan lewat internet dan otomatis tanah milik PT. KAl akan dipergunakan untuk pembangungan jalur ganda. Warga Pulosari merasa ikhlas dan percaya dengan pemerintah bahwa pembangunan ini akan berdampak positif bagi Kota Malang agar semakin maju lagi, dan juga dapat mengurangi angka kemacetan di Kota Malang. Bila memang jalan alternatif warga Pulosari akan terganggu maka pemerintah juga akan memikirkan bagaimana cara mensejahterakan warga Pulosari dengan adanya suatu ganti rugi dari pemerintah Kota Malang. Akan tetapi berbeda kondisinya dengan warga Pulosari yang bertempat tinggal di pinggir rel, mereka memiliki pandangan lain mengenai hal ini, bahwa mereka tidak percaya dan merasa kecewa dengan kebijakan pemerintah tentang ganti rugi yang mungkin akan diberikan dalam pembangunan jalur ganda ini dikarenakan masyarakat beranggapan pemerintah kurang memperhatikan masyarakat kecil yang tinggal di pinggir rel kereta api. Kedua kondisi ini menunjukkan masyarakat memiliki persepsi yang berbeda-beda mengenai kebijakan dari pemerintahan tersebut. Seseorang yang memiliki persepsi negatif terhadap suatu objek akan mempengaruhi sikap mereka yaitu dengan menolak atau tidak mendukung (Listyana \& Hartono, 2015). Akan tetapi, bila seseorang memiliki persepsi positif terhadap suatu objek maka akan cenderung mendukung bahkan tertarik terhadap objek tersebut (Arifianto \& Sukanti, 2014). Persepsi sosial merupakan salah satu faktor psikologis dan faktor sosial yang dapat mempengaruhi setiap individu. Manusia memiliki suatu persepsi yang berbeda-beda. Persepsi mencakup kesadaran dalam suatu peristiwa, orang, objek, dan situasi dan membutuhkan pencarian, perolehan dan pemrosesan informasi. Persepsi interaksi sosial adalah suatu proses aktif yang dapat menghasilkan suatu pandangan mengenai orang lain, persepsi ini juga memiliki bentuk positif dan negatif yang berbeda-beda (Lopes, Brackett, Nezlek, Schutz, Sellin, \& Salovey, 2004).

Persepsi mencakup kesadaran akan peristiwa, orang, objek, dan situasi dan membutuhkan pencarian, perolehan, dan pemrosesan informasi (Samadifardi \& Damirchi, 2018). Setiap pandangan yang dimiliki seseorang terhadap suatu kejadian akan mendasari perilaku maupun perasaan dari setiap inidvidu. Warga Pulosari memiliki persepsi bahwa kebijakan dari pemerintah tentang akan dibangunnya jalur ganda kereta api ini maka alat transportasi darat akan semakin maju dan juga mengurangi angka kemacetan khusunya di wilayah Kota Malang sendiri, akan tetapi hal tersebut juga masih menimbulkan kekhawatiran yang disebabkan tempat tinggal mereka akan terancam bahkan bisa juga mereka akan digusur. Basharpoor, Narimani, dan Esazadeghan (dalam Basharpoor, Heydarirad, Daryadel, Heydari, Givi, \& Kishore, 2017) mendefinisikan persepsi positif terkait stres, individu menganggap stres merupakan suatu hal yang positif dan mampu dalam mengatasi stres. Tetapi dalam persepsi negatif terkait stres, individu merasa tidak mampu mengatasi suatu permasalahan dan mengahadapi tantangan yang timbul dengan tidak kesengajaan serta 
menunjukkan reaksi negatif berupa ketakutan, kecemasan, kurang percaya diri, dalam menghadapi permasalahan.

Tujuan dalam penelitian ini yaitu untuk mengetahui hubungan persepsi terhadap pemerintah dan kecemasan dalam menghadapi rencana pembangunan jalur ganda kereta api pada warga Pulosari Kecamatan Blimbing Kota Malang. Manfaat praktis dari penelitian ini yaitu untuk memberikan persepsi yang positif bagi warga Pulosari tehadap kebijakan pemerintah dan juga warga Pulosari dapat mengatasi kecemasan dalam menghadapi rencana pembangunan jalur ganda kereta api. Manfaat teoritis dari penelitian ini yaitu menambah referensi bagi peneliti selajutnya mengenai persepsi dan juga kecemasan.

\section{Metode Penelitian}

Penelitian ini menggunakan pendekatan kuantitatif yaitu data yang dikumpulkan berupa data kuantitatif kemudian diolah menggunakan statistik. Desain penelitian yang digunakan adalah korelasional. Tujuan penelitian korelasi adalah untuk mengetahui ada tidaknya hubungan dalam variabel dan jika memang memiliki hubungan, seberapa besar hubungan diantara kedua variabel tersebut (Arikunto, 2010).

\section{Subjek Penelitian}

Pengambilan sampel pada penelitian ini menggunakan teknik purposive sampling yaitu teknik penelitian dengan membuat kriteria khusus terhadap subjek penelitian (Periantalo, 2016). Oleh karena itu, peneliti menggunakan teknik purposive sampling dengan mempertimbangankan kriteria yang harus dimiliki oleh sampel yang digunakan pada penelitian. Subyek pada penelitian ini adalah warga dari Kampung Pulosari sejumlah 77 orang yang bertempat tinggal di pinggir rel kereta api. Adapun kriteria dalam penelitian ini adalah warga Pulosari Kelurahan Purwodadi Kecamatan Blimbing Kota Malang, bertempat tinggal di pinggir rel kereta api yaitu warga RT 01, RT 02, RT 03, RT 04, dan RT 06 dan minimal berusia dewasa.

\section{Variabel dan Instrumen Penelitian}

Pada penelitian ini terdapat dua variabel yakni variabel bebas $(X)$ dan variabel terikat $(Y)$. Adapun yang menjadi variabel bebas $(X)$ yaitu persepsi masyarakat terhadap pemerintah dan variabel terikat $(\mathrm{Y})$ adalah kecemasan masyarakat dalam menghadapi rencana pembangunan jalur ganda kereta api.

Definisi operasional dari kecemasan merupakan suatu keadaan tidak nyaman yang dapat mempengaruhi emosi, dimana individu merasa terancam, dan juga merasa khawatir dalam menghadapi bahaya. Tinggi rendahnya kecemasan pada warga Pulosari dilihat dari hasil skala, semakin tinggi hasil yang diperoleh subjek penelitian, maka semakin tinggi tingkat kecemasan yang dimiliki, sedangkan semakin rendah hasil yang diperoleh subjek penelitian, maka semakin rendah pula tingkat kecemasan yang dimiliki. Skala psikologi yang dipakai dalam penelitian ini yaitu skala kecemasan yang diambil dari 3 aspek kecemasan yaitu fisik, perilaku, dan kognitif dari (Nevid, Rathus, \& Greene, 2003) sejumlah 20 item. 
Definisi operasional dari persepsi adalah pandangan seseorang, penginterpretasian pada indera, sehingga menjadi suatu respon yang ada dalam diri individu. Persepsi setiap individu berbeda-beda maka inilah yang menyebabkan individu memiliki persepsi terhadap pemerintah yang berbeda-beda. Skala psikologi yang dipakai dalam penelitian ini adalah skala persepsi yang diambil dari 3 aspek persepsi yaitu kognitif, afektif, dan konatif dari Taylor, Peplau, dan Sears (2009) sejumlah 18 item.

Skala kecemasan dan skala persepsi pada penelotian ini menggunakan skala likert yang terdiri dari item favorable dan unfavorable. Pada kedua skala tersebut terdapat empat respon dalam pilihannya yaitu SS (sangat setuju), S (setuju), TS (tidak setuju), dan STS (sangat tidak setuju). Respon dari item favorable memiliki nilai empat untuk respon sangat setuju, nilai tiga untuk respon setuju, nilai dua untuk respon tidak setuju, dan nilai satu untuk respon sangat tidak setuju. Respon dari item unfavorable akan memiliki bobot nilai satu untuk respon sangat setuju, nilai dua untuk respon setuju, nilai tiga untuk respon tidak setuju, dan nilai empat untuk respon sangat tidak setuju.

Tabel 1. Indeks Validitas dan Reliabilitas Alat Ukur Penelitian (Aiken's V)

\begin{tabular}{llll}
\hline Alat Ukur & Jumlah Item & Indeks & Indeks \\
& Valid & Validitas Isi & Reliabilitas \\
\hline Persepsi & 18 & $0,5-0,87$ & 0,936 \\
Kecemasan & 20 & $0,5-0,93$ & 0,929 \\
\hline
\end{tabular}

Berdasarkan hasil uji validitas dan reliabilitas pada alat ukur persepsi dan kecemasan, diperoleh skala persepsi dengan jumlah 18 item yang valid dapat digunakan untuk mengukur persepsi. Indeks validitas isi dari skala persepsi bergerak dari 0,5 sampai 0,87 dan nilai indeks reliabilitasnya sebesar 0,936 . Kemudian pada skala kecemasan dengan jumlah item yang valid terdapat 20 item, memiliki indeks validitas isi yang bergerak dari 0,5 sampai 0,93 dan nilai indeks reliabilitas sebesar 0,929.

\section{Prosedur dan Analisa Data.}

Penelitian ini memiliki tiga prosedur utama yang dilakukan. Tahap pertama yaitu persiapan, pada tahap ini peneliti menentukan judul dari berita kejadian atau fenomena yang terjadi di lapangan. Kemudian peneliti menentukan rumusan masalah dan juga teori yang digunakan. Selanjutnya, peneliti menentukan teknik pengambilan sampel dan membuat instrumen untuk pengumpulan data yang sesuai dengan teori. Langkah selanjutnya peneliti melakukan proses uji validitas isi pada skala kecemasan dan skala persepsi menggunakan rumus Aiken's $V$ pada 10 orang rater dan melakukan uji reliabilitas. Tahap kedua adalah tahap pelaksanaan, yaitu setelah diperoleh skala yang sudah valid dan reliabel maka peneliti mulai menyebarkan skala kepada subjek penelitian yaitu warga Pulosari Kecamatan Blimbing Kota Malang. Penyebaran dilakukan dengan teknik purposive sampling yaitu metode pengambilan sampel yang dipilih secara cermat sehingga relevan dengan struktur penelitian dimana pengambilan sampel dari orang-orang yang dipilih oleh peneliti berdasarkan karakteristik tertentu. Tahap ketiga adalah tahap analisa, pada tahap ini peneliti menganalisa hasil dari penyebaran kedua skala. Data-data yang telah diperoleh kemudian diinput dan diolah dengan program perhitungan statistik SPSS 21 , menggunakan uji korelasi product moment pearson. 


\section{Hasil Penelitian}

Pengambilan data penelitian ini dengan cara menyebarkan skala pada warga Pulosari yang bertempat tinggal di pinggir rel kereta api. Total subjek dalam penelitian ini yaitu 77 subjek yang memenuhi kriteria dalam penelitian ini, berikut data demografinya.

Tabel 2. Deskripsi Subjek Penelitian

\begin{tabular}{|c|c|c|}
\hline Kategori & Frekuensi & Persentase (\%) \\
\hline \multicolumn{3}{|l|}{ Usia } \\
\hline 19 - 33 tahun & 36 & $47 \%$ \\
\hline $34-48$ tahun & 15 & $30 \%$ \\
\hline $49-63$ tahun & 23 & $19 \%$ \\
\hline $64-75$ tahun & 3 & $4 \%$ \\
\hline Total & 77 & $100 \%$ \\
\hline \multicolumn{3}{|l|}{ Jenis Kelamin } \\
\hline Laki-Laki & 51 & $66 \%$ \\
\hline Perempuan & 26 & $34 \%$ \\
\hline Total & 77 & $100 \%$ \\
\hline \multicolumn{3}{|l|}{ Alamat } \\
\hline RT 1 & 12 & $16 \%$ \\
\hline RT 2 & 19 & $25 \%$ \\
\hline RT 3 & 9 & $12 \%$ \\
\hline RT 4 & 22 & $29 \%$ \\
\hline RT 6 & 15 & $19 \%$ \\
\hline Total & 77 & $100 \%$ \\
\hline
\end{tabular}

Dari tabel 2 di atas diketahui, bahwa dari 77 subjek terdapat jumlah subjek yang berusia antara 19-33 tahun (47\%), 34-48 tahun (30\%), 49-63 tahun (19\%), dan 64-75 tahun (4\%). Berdasarkan jenis kelamin dari 77 responden yang berjenis kelamin laki laki terdapat 51 subjek (66\%) dan perempuan terdapat 26 subjek (34\%). Sedangkan berdasarkan tempat tinggal subjek yang berada di pinggir rel, dari RT 1 sebanyak 12 subjek (16\%), RT 2 sebanyak 19 subjek, RT 3 sebanyak 9 subjek (12\%), RT 4 sebanyak 22 subjek (29\%), dan RT 6 sebanyak 15 orang (19\%). Selanjutnya untuk melihat perbedaan tingkat persepsi dan kecemasan berdasarkan jenis kelamin sebagai berikut.

Tabel 3. Tingkat Persepsi Berdasarkan Jenis Kelamin

\begin{tabular}{lllll}
\hline Variabel & Kategori & Laki laki & Perempuan & Total \\
\hline \multirow{2}{*}{ Persepsi } & Positif & 25 & 17 & 42 \\
& Negatif & 26 & 9 & 35 \\
\hline
\end{tabular}

Berdasarkan tabel 3 di atas diketahui, bahwa subjek laki laki yang memiliki persepsi positif terhadap pemerintah sebanyak 25 subjek dan subjek perempuan yang memiliki persepsi positif terhadap pemerintah sebanyak 17 subjek. Kemudian, subjek laki laki yang memiliki persepsi negatif terhadap pemerintah sebanyak 26 subjek dan subjek perempuan yang memiliki persepsi negatif terhadap 
pemerintah sebanyak 9 subjek.

Tabel 4. Tingkat Kecemasan Berdasarkan Jenis Kelamin

\begin{tabular}{lllll}
\hline Variabel & Kategori & Laki laki & Perempuan & Total \\
\hline \multirow{2}{*}{ Kecemasan } & Tinggi & 29 & 13 & 42 \\
& Rendah & 22 & 13 & 35 \\
\hline
\end{tabular}

Berdasarkan tabel 4 di atas diketahui, bahwa subjek laki laki yang memiliki kecemasan tinggi sebanyak 29 subjek, subjek perempuan yang memiliki kecemasan tinggi sebanyak 13 subjek. Subjek laki laki yang memiliki kecemasan rendah sebanyak 22 subjek, subjek perempuan yang memiliki kecemasan rendah sebanyak 13 subjek.

Sebelum melakukan uji korelasi, dilakukan uji kenormalan data dengan menggunakan Skewnesskurtosis dengan syarat diantara \pm 2 . Pada variabel persepsi, nilai skewness setelah dibagi nilai standart error berjumlah $-0,055$ dan nilai kurtosis sebesar $-0,739$. Hal ini menunjukkan bahwa data normal.

Tabel 5. Uji Hipotesa

\begin{tabular}{ll}
\hline Ketentuan & Nilai \\
\hline$r$ & $-0,74$ \\
$r^{2}$ & 0,55 \\
$P$ & 0,01 \\
Keterangan & Signifikan \\
\hline
\end{tabular}

Hasil uji hipotesa ini mendapat nilai signifikan 0,01 < 0,05 maka hipotesa diterima, yang artinya terdapat hubungan yang signifikan antara persepsi masyarakat terhadap pemerintah dengan kecemasan menghadapi rencana pembangunan jalur ganda kereta api pada warga Pulosari Kecamatan Blimbing Kota Malang. Dari hasil uji hipotesa menunjukkan nilai $r$ adalah $-0,74$ menunjukan hubungan yang negatif yang artinya bahwa semakin persepsi terhadap pemerintah positif, semakin tidak menimbulkan kecemasan. Begitupun sebaliknya, persepsi terhadap pemerintah negatif maka menimbulkan kecemasan pada warga Pulosari dalam menghadapi rencana pembangunan jalur ganda kereta api. Hal ini dapat dilihat dari kontribusi atau $r^{2}$ persepsi terhadap kecemasan sebesar 0.55 dengan persentase sebesar $55 \%$.

\section{Pembahasan}

Penelitian ini dilakukan untuk mengetahui hubungan antara hubungan persepsi masyarakat terhadap pemerintah dengan kecemasan menghadapi rencana pembangunan jalur ganda kereta api pada warga Pulosari Kecamatan Blimbing Kota Malang. Berdasarkan hasil analisa dengan menggunakan uji korelasi product moment pearson, diperoleh nilai koefisien korelasi $(r)$ sebesar - 
0,74 dengan nilai signifikan ( $p$ ) sebesar 0,01<0,05. Dari hasil uji hipotesa menunjukkan bahwa kedua variabel memiliki hubungan negatif yang artinya semakin persepsi masyarakat terhadap pemerintah negatif maka menimbulkan kecemasan pada warga Pulosari dalam menghadapi rencana pembangunan jalur ganda kereta api, begitupun sebaliknya.

Berdasarkan data dari tabel 5 menunjukkan nilai $R$ square $\left(r^{2}\right)$ sebesar 0,55 yang artinya bahwa $55 \%$ variabel persepsi masyarakat terhadap pemerintah memberikan dampak yang cukup besar pada variabel kecemasan menghadapi rencana pembangunan jalur ganda kereta api pada warga Pulosari. Sedangkan sisanya dipengaruhi oleh beberapa faktor lain yang tidak dimasukkan dalam penelitian ini seperti, dukungan sosial, regulasi diri, konsep diri dan lain-lain. Persepsi individu ini dipengaruhi oleh beberapa faktor dari dalam dirinya atau faktor individu dan juga faktor yang berasal dari luar dirinya atau faktor lingkungan (Fuadi, Arifin, \& Kuswarno, 2017). Hubungan dari kedua variabel ini tergolong dalam kategori besar, yang artinya bagaimana persepsi warga Pulosari yang bertempat tinggal di pinggir rel kereta api terhadap pemerintah ini juga dapat mempengaruhi tingkat kecemasan warga Pulosari dikarenakan rumah yang akan ditinggali warga terancam dan juga jalan alternatif yang semula dapat dilewatin kendaraan roda empat akan tidak bisa dilewati lagi. Menurut penelitian Riani dan Rozali (2014) Individu yang memberikan penilaian mengenai ketidakyakinan dirinya dalam menghadapi suatu situasi yang baru dapat menimbulkan munculnya perasaan cemas yang berupa keringat dingin pada tubuh, jantung berdebar debar

Berdasarkan hasil data dari tabel 3 dan 4 diperoleh dari perhitungan kategori menunjukkan bahwa warga Pulosari dengan jenis kelamin perempuan dan laki-laki memiliki persepsi positif terhadap pemerintah, mereka beranggapan bahwa pemerintah tidak akan tinggal diam dengan rencana pembangunan jalur ganda kereta api ini. Warga Pulosari percaya kepada pemerintah bahwa pemerintah akan memberikan suatu kebijakan atau ganti rugi terhadap rumah warga yang terkena dampak dari jalur ganda kereta api, hal ini sesuai dengan penelitian yang menyatakan bahwa bila seseorang memiliki persepsi positif terhadap suatu objek maka akan cenderung mendukung bahkan tertarik terhadap objek tersebut (Arifianto \& Sukanti, 2014). Di sisi lain, warga Pulosari dengan jenis kelamin laki-laki memiliki tingkat kecemasan pada kategori tinggi dibandingkan dengan yang perempuan. Warga Pulosari dengan jenis kelamin laki-laki merasa cemas bila rumah yang ditinggali akan terancam tergusur. Mereka merasa pusing bila nanti rumahnya akan digusur ditambah lagi apabila pemerintah tidak memberikan ganti rugi bagi rumah yang terkena dampak dari pembangungan jalur ganda kereta ini. Menurut penelitian Purwastuty (2019), kepala keluarga mengalami tingkat kecemasan yang berbeda-beda, ada yang hanya mengalami kecemasan tingkat sedang dan hanya butuh menghindari sumber ketakutannya, tetapi ada pula yang mendapat serangan panik yang membuatnya tidak nyaman. Selain itu, Warga Pulosari terutama laki-laki mengalami kecemasan bilamana nantinya rumah yang ditinggalinya akan terancam terkena penggusuran karena pembangunan tersebut dan kehilangan mata pencaharian dikarenakan pembangunan jalur ganda kereta api. Hal ini sejalan dengan penelitian Videbeck (dalam Fauziyah, Rafiyah, \& Solehati, 2018) menyatakan bahwa orang yang berada pada sosial ekonomi rendah akan lebih berpotensi mengalami kecemasan lebih sering.

Pada penelitian ini terlihat dari variabel persepsi memiliki kategori negatif pada 35 subjek terhadap pemerintah, Kemudian terdapat 42 subjek warga Pulosari yang memiliki kecemasan dalam menghadapi pembangunan jalur ganda kereta api memiliki kategori tinggi, hal ini sesuai dengan 
penelitian Listyana dan Hartono (2015) seseorang yang memiliki persepsi negatif terhadap suatu objek akan mempengaruhi sikap mereka yaitu dengan menolak atau tidak mendukung, sikap menolak dan tidak mendukung ini menyebabkan suatu gangguan kecemasan, dalam hal ini sejalan dengan penelitian Maina, Mauri, \& Rossi (2016) gangguan cemas yang dialami inidividu disebabkan oleh meningkatnya tingkat perasaan khawatir dan meningkatnya perasaan tegang pada situasi yang ditakuti, dan menghindari rangsangan atau keadaan yang dapat memicu timbulnya perasaan cemas.

Masyarakat yang memiliki persepsi positif dan negatif terhadap pemerintah berdampak pada perasaan cemas atau tidak cemas. Selain itu dalam penelitian sebelumnya menunjukan bahwa persepsi juga memiliki bentuk positif dan negatif yang berbeda-beda (Lopes, Brackett, Nezlek, Schutz, Sellin, \& Salovey, 2004). Persepsi negatif terhadap pemerintah menimbulkan suatu perasaan cemas pada warga Pulosari. Seperti pada tabel 4 bahwa nilai $r-0.74$, yang artinya terdapat hubungan yang negatif antara variabel persepsi dan variabel kecemasan yang artinya semakin positif persepsi terhadap pemerintah, semakin tidak menimbulkan kecemasan. Begitupun sebaliknya, semakin negatif persepsi terhadap pemerintah maka menimbulkan kecemasan pada warga Pulosari dalam menghadapi rencana pembangunan jalur ganda kereta api.

Penelitian ini memiliki kelebihan dan kekurangan, dimana kelebihan dari penelitian ini adalah topik atau tema yang diangkat peneliti ini sangat jarang ditemui atau dibahas sehingga menarik untuk diteliti serta dapat menjadi sumber pengetahuan yang baru dalam bidang Psikologi sosial. Kekurangan dari penelitian ini adalah peneliti tidak menanyakan jenjang pendidikan pada subjek penelitian, dan penelitian ini menggunakan metode self report.

\section{Kesimpulan}

Berdasarkan hasil penelitian yang telah dilakukan oleh peneliti, diketahui bahwa terdapat hubungan negatif antara persepsi terhadap pemerintah dengan kecemasan mengahadapi rencana pembangunan jalur ganda kereta api pada warga Pulosari.

Implikasi yang diperoleh dalam penelitian ini yaitu diharapkan dapat menambah pengetahuan ilmiah bagi warga Pulosari bahwa dengan mengetahui persepsi positif terhadap pemerintah tidak akan menimbulkan suatu perasaan cemas dalam menghadapi rencana pembangunan jalur ganda kereta api dan juga pemerintah harus lebih transparansi informasi terkait dengan pembangunan jalur ganda kereta api dan juga soal kebijakan dari pembangunan tersebut. Hasil penelitian ini dapat menjadi referensi untuk penelitian yang memiliki tema sejenis dengan cara memperluas ruang lingkup penelitiannya. Kemudian untuk peneliti selanjutnya dapat menambah variabel yang lain. 


\section{Daftar Pustaka}

Arifianto, F., \& Sukanti. (2014). Pengaruh motivasi diri dan persepsi mengenai profesi akuntan publik terhadap minat menjadi akuntan publik pada mahasiswa prodi akuntansi fakultas ekonomi universitas negeri Yogyakarta. Jurnal Nominal., 33 (2). https://doi.org/10.21831/nominal.v3i2.2700

Arikunto, S. (2010). Prosedur penelitian suatu pendekatan praktik. rev.ed. Jakarta: PT. Rineka Cipta.

Basharpoor, S., Heydarirad, H., Daryadel, S., J., Heydari, F., Givi, H., G., \& Kishore, J. (2017). The role of perceived stress and social support among predicting anxiety in pregnant women. Journal of Holistic Nursing and Midwifery, 9-16. DOI: 10.18869/acadpub.hnmj.27.2.9

Fauziyah, N., Rafiah, I., \& Solehati, T. (2018). Parent's anxiety towards juvenile deliquency phenomenon in Bandung Indonesia. NurseLine Journal, 3(2), 52-59.

Fuadi, I., Arifin, H. S., \& Kuswarno, E. E. (2017). Analisis faktor yang mempengaruhi persepsi mahasiswa untirta terhadap keberadaan perda syariah di Kota Serang. Jurnal Penelitian Komunikasi dan Opini Publik, 21(1).

Hermawan, A. (2016). Pembangunan rel kereta api ganda di Jawa Timur dikebut tahun ini. Suara.com. https://www.suara.com/bisnis/2016/03/25/160207/pembangunan-rel-keretaapi-ganda-di-jawa-timur-dikebut-tahun-ini

Iskandar, Y. (2015). Double track Surabaya-Malang tunggu giliran. Tribun News.com http://www.tribunnews.com/regional/2015/01/14/double-track-surabaya malang-tunggugiliran.

Listyana, R., \& Hartono, Y. (2015). Persepsi dan sikap masyarakat terhadap penanggalan Jawa dalam penentuan waktu pernikahan studi kasus desa Jonggrang kecamatan Barat kabupaten Magetan tahun 2013. Jurnal Agastya, 5 (1).

Lopes, P. N., Brackett, M. A., Nezlek, J. B., Schutz, A., Sellin, I., \& Salovey, P. (2004). Emotional intelligence and social interaction. Personality and social psychology bulletin, 30 (8), 10181034.

Maina, G., Mauri. M., \& Rossi. A. (2016). Anxiety and depression. Journal of Psychopathology, 22, 236-250.

Mohtasham, L., \& Farnia, M. (2017). English speaking anxiety: A study of the effect of gender on Iranian efl university students perceptions. International Journal Research in English education, 2(4).

Nevid, J., S., Rathus, S.A., \& Greene, B. (2003). Psikologi abnormal edisi 5. Jakarta: Erlangga. 
Budi Cakra Buana dan Udi Rosida Hijrianti

Praditya, I. (2016) Rusia Mulai Studi Proyek Jalur Ganda Kereta Surabaya Malang. https://www.liputan6.com/bisnis/read/2647504/rusia-mulai-studi-proyek-jalur-ganda kereta-surabaya-malang.

Periantalo, J. (2016). Penelitian kuantitaif untuk psikologi. Yogyakarta: Pustaka pelajar

Purwastuty, I. (2019). Kecemasan masyarakat terhadap bencana banjir bandang di Desa Batuganda Kecamatan Lasusua Kabupaten Kolaka Utara. Jurnal Mimbar Kesejahteraan Sosial, 2(2).

Riani, W., S. \& Rozali, Y., A. (2014). Hubungan antara self efficacy dan kecemasan saat presentasi pada mahasiswa Univeristas Esa Unggul. Jurnal Psikologi Esa Unggul, 12(01).

Samadifardi, H., R., \& Damirchi, E., S. (2018). The relationship between perception of social interaction, perceived social support and social acceptance with aggression among adolescents. Journal of Research \& Health Social Development \& Health Promotion Research Center. 8(1), 38- 46. DOI: 10.29252/acadpub.jrh.8.1.38

Taylor, S. E., Peplau, L. A., \& Sears, D.O. (2009). Psikologi sosial. Jakarta: Kencana Prenada Media Group.

Undang Undang Nomer 23 Tahun 2007 tentang Perkeretaapian.

Wani, M. A., Sankar, R., Rakshantha, P., Nivatha, A. L. S., Sowparnika, C. E., \& Marak, L.D. B. (2016). Stress anxiety and depression among science and arts students. International Journal of Education and Psychological Research, 5(3), 48-51 